\title{
Desenvolvimento e transferência de tecnologia \\ tecnológico
}

José Adeodato de Souza Neto, vice-presidente da Financiadora de Estudos e Projetos - Finep
Parece que o principal mecanismo de promover e estimular o desenvolvimento tecnológico é através do poder de compra do governo, como se faz nos Estados Unidos da América do Norte.

Em outros países, acredito que no caso da França e Inglaterra, por exemplo, o governo tem outras formas de atuação: além do poder de compra ele intervém mais diretamente na economia, aportando recursos subsidiados, como é o caso da Agence Nationale pour la Valorisation de la Recherche - , na França, que pratica a chamada valorização da pesquisa.

Ao longo desses últimos quinze anos, o Brasil fez investimentos relativamente grandes na sua capacitação científica e tecnológica, tanto assim que, de uma hora para outra, nós estávamos em terceiro ou quarto lugar na lista de publicações científicas no Terceiro Mundo e, de repente, passamos para o segundo lugar. Somente a India publica mais artigos científicos em revistas nacionais e internacionais do que o Brasil. Passamos, com certeza, a Argentina, que estava na nossa frente, e tenho impressão de que - México também estava na nossa frente. De outro lado, houve grande investimento do lado do setor industrial, em especial na área de máquinas e equipamentos, indústrias de base, etc., que foi resultado de uma política muito bem-planejada e incrementada pelo governo, através do BNDES, que resultou num progresso muito grande.

Entretanto, surge a questão tecnológica. Acho que existe hoje certo vazio entre aquilo que é produzido nas universidades e nas instituições governamentais e paragovernamentais e o setor econômico. Acho que esta é uma outra política que poderia ser praticada com um pouco mais de inteligência, inclusive a Finep, o CNPq, os órgãos responsáveis por isso, têm tomado acões, mas esse filão me parece bastante fértil. Foi dito que a indústria sozinha não pode assumir todo esse ônus de desenvolvimento tecnológico, quer dizer depende de desenvolvimento científico e tem um alto risco, e diria, o instrumento de financiamento com subsídio é um
José Adeodato de Souza Neto

dos instrumentos; entretanto, essa aproximação de instituições sem fins lucrativos, que desenvolvem pesquisas e que já têm um potencial humano razoavelmente desenvolvido, avançado, será seguramente uma forma de apoio à indústria e não aparecerá como um subsídio, conforme foi mencionado aqui.

De outro lado, gostaria de comentar mais um aspecto que é o seguinte: todo o nosso desenvolvimento econômico foi pautado na substituição de importações. A nossa capacidade imitativa na qualidade de uma economia periférica é bastante grande, ou seja, o que nós fazemos hoje efetivamente tanto em ciência como em tecnologia, salvo algumas exceções, é tentar reproduzir aquilo que está sendo feito nos países desenvolvidos. Então, acho que uma política de mais longo prazo que, seguramente deveria ser implementada, e seria a de incentivar, estimular, a nossa criatividade, lançando no mercado novas técnicas, novos produtos que não necessariamente tenham similares, mas que sejam novos produtos no mercado. Eaí eu me refiro ao processo de comunicação entre laboratório e o mercado. Este é um processo de duas vias: seguramente quando a demanda um do mercado ao laboratório, é um processo gestionável, ou seja, existem técnicas de gestão, de administração, que lhe permite trazer uma demanda de mercado, levar ao laboratório e voltar com a solução.

O processo reverso, que é o processo de estimular a criatividade e levar ao mercado alguma coisa inovadora, este é um processo mais difícil de gestionar. Ele tem uma percentagem muito grande de sabor aleatório. Entretanto, é somente através desse mecanismo que se conseguem os grandes avanços, as grandes descobertas; as grandes inovações são efetivamente produzidas inicialmente sem uma aplicação, uma perspectiva. Portanto, acho que as nossas universidades, as nossas instituições de pesquisas, sejam privadas ou públicas, merecem o apoio, para que possam exercitar sua criatividade e, conseqüentemente, produzir a inovação ou o grande salto científico ou tecnológico. 